\begin{tabular}{lcr} 
FOLIA & ENTOMOLOGICA & HUNGARICA \\
& ROVARTANI KÖZLEMÉNYEK & \\
Volume 81 & 2020 & pp. $27-32$ \\
\hline
\end{tabular}

\title{
A contribution to the knowledge of Thorictus Germar, 1834 from Afghanistan \\ (Coleoptera: Dermestidae: Thorictinae)
}

Jiří HÁva

\begin{abstract}
Forestry and Game Management Research Institute, Strnady 136, CZ-156 00 Praha 5 - Zbraslav, Czech Republic.E-mail: jh.dermestidae@volny.cz
\end{abstract}

\begin{abstract}
Thorictus merkli sp. n. from Afghanistan is described, illustrated and compared with similar species. With 5 figures.
\end{abstract}

Key words - beetles, myrmecophily, new species, taxonomy

\section{INTRODUCTION}

The myrmecophilous dermestid genus Thorictus Germar, 1834 currently includes 170 species and subspecies known from the Palaearctic, Oriental and Afrotropical regions (HÁva 2015, 2020). Species from Afghanistan were described by JoH N $(1962,1964)$.

During the identification of dermestid specimens I found a new species of Thorictus from Afghanistan. It is described below.

\section{MATERIAL AND METHODS}

The following measurements were made: $\mathrm{BL}=$ body length (measured from the head anterior margin to the apex of the elytra); BW = body width (measured between two anterolateral humeral calli). All measurements are given in millimetres. Text of the locality labels are cited verbatim.

Male genitalia were not studied. The differential diagnosis of the aedeagi is often problematic, and interspecific variation is currently very poorly defined (JoHN 1963). The setation of the thoracic venter of the four studied species is illustrated (Figs 1-4). The two species groups considered here were established by JoHN (1963). 
The type specimens are deposited in the following collections: FGMRI = Forestry and Game Management Research Institute, Prague, Czech Republic; HNHM = Hungarian Natural History Museum, Budapest, Hungary.

\section{RESULTS}

Thorictus walanganus John, 1964

(Fig. 1)

Type material - Holotype: O-Afghanistan, Hindukusch, Walang, Salangtal, 2520 m, IX.1952, J. Klapperich (HNHM).

\section{Thorictus khinjanus John, 1964}

(Fig. 2)

Type material - Holotype: O-Afghanistan, Hindukusch, Khinjantal, DoSchak, 2500 m, 1.X.1952, J. Klapperich (HNHM).

Thorictus kabulanus John, 1964

(Fig. 3)

Type material - Holotype: O-Afghanistan, Umgebung von Kabul, 1740 m, III.1953, J. Klapperich (HNHM).

\section{Thorictus merkli sp. n.}

(Fig. 4)

Type material - Holotype: „Afghanistan-650, Col de Sabxxak (à 65 km au nord-est de Hérat), 4.vi.1959, K. Lindberg" / "Au bord d'une mare de torrent à $110 \mathrm{~m}$ au-dessous du col., Alt. $2340 \mathrm{~m}$ " (FGMRI). The holotype is provided with red, printed label with the text as follows: „HOLOTYPE Thorictus merkli sp. nov. Jiří Háva det. 2020".

Description - Body large (for a Thorictus), oval, dark brown, covered by short, yellow setae on dorsal and ventral surfaces. Measurements (mm): BL 2.53, BW 1.45. Head finely punctate with very short, yellow, recumbent setae. Labial palpi entirely brown. Antennae brown, with 11 antennomeres, antennal club compact, with 3 antennomeres, antennomere 11 short and broad, with 
short yellow setae. Eyes small with microsetae. Lateral eyes on head with very small granules. Pronotum as finely punctate as head, covered by short, yellow, recumbent setation. Lateral margin of pronotum without fine dentation. Posterior corners without long yellow setae. Ventral posterior pronotal corners without yellow setation. Scutellum small, triangular, without setation. Elytra very finely punctate, covered by short, recumbent, yellow setae; lateral yellow setation erect; with two depressions in anterior half near scutellum. Epipleuron finely punctate, anterior corners with large bump; bump coarsely punctured, with yellow setation. Prosternum coarsely punctate. Mesosternum with small, foveolate punctures. Metasternum finely punctate. Setation on margin of thoracic venter as on Fig. 4. Abdominal ventrites very finely punctate, covered by very short, recumbent, yellow setae. Striation on first abdominal ventrite very short. Legs dark brown, covered by golden-yellow setae.

Differential diagnosis - The new species belongs to the T. orientalis species group according to characters stated by JoHN (1963), and is very similar to Thorictus khinjanus John, 1964 and Thorictus walanganus John, 1964, but differs from them by the setation on the thoracal margin in ventral view. From the extremely similar Thorictus kabulanus John, 1964 it differs by its shine and setation on the thoracal margins (Figs 1-4).

Etymology - Patronymic, dedicated to my friend and curator of Coleoptera in HNHM, Ottó Merkl.

\section{LIST OF THORICTUS SPECIES FROM AFGHANISTAN}

The type localities of the seven species are indicated on Fig. 5.

Thorictus angustus John, 1964

Thorictus kabulanus John, 1964

Thorictus kandaharicus John, 1962

Thorictus khinjanus John, 1964

Thorictus merkli sp. $\mathrm{n}$.

Thorictus quinquesulcatus John, 1964

Thorictus walanganus John, 1964 
1

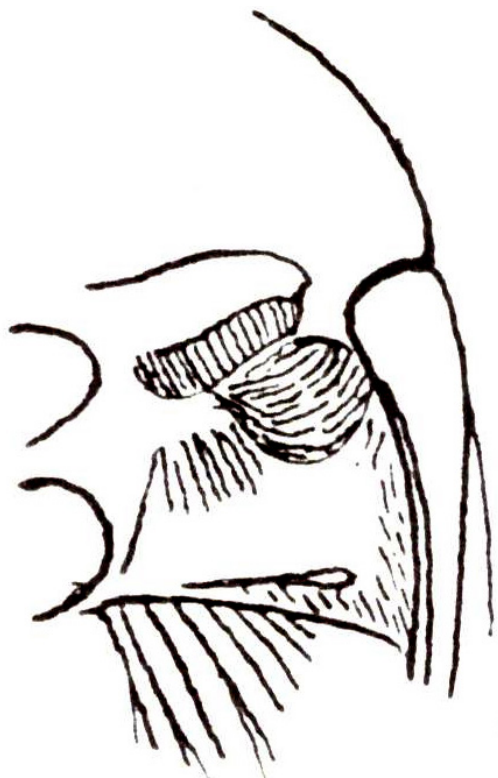

3

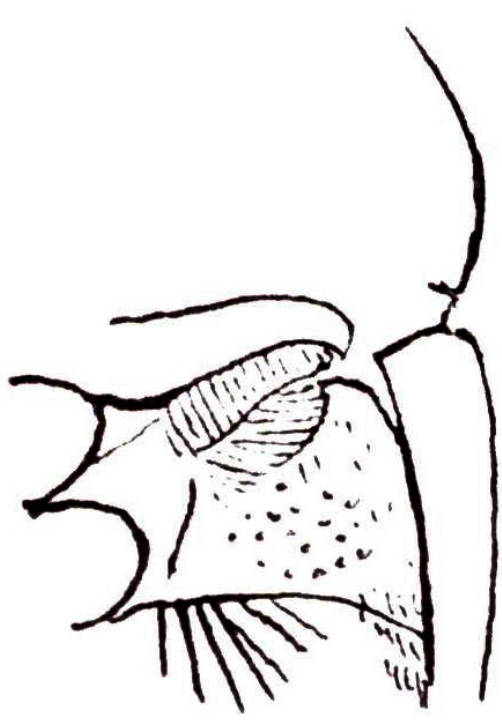

2

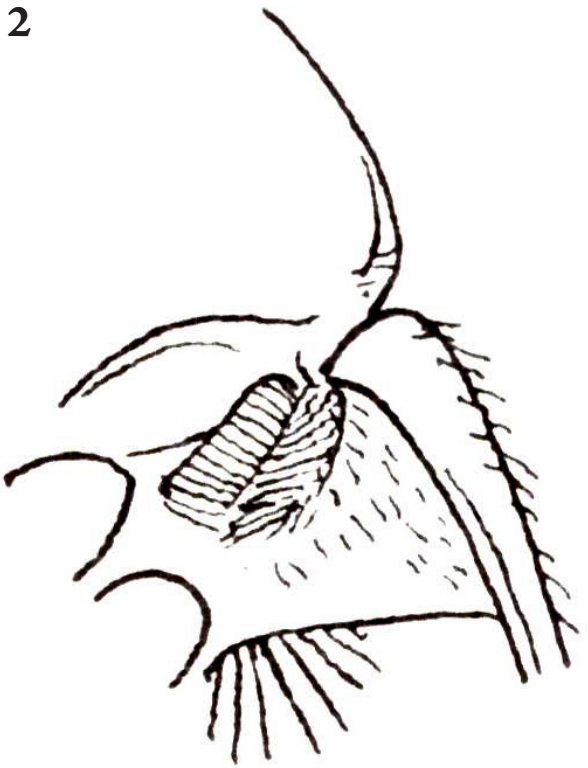

4

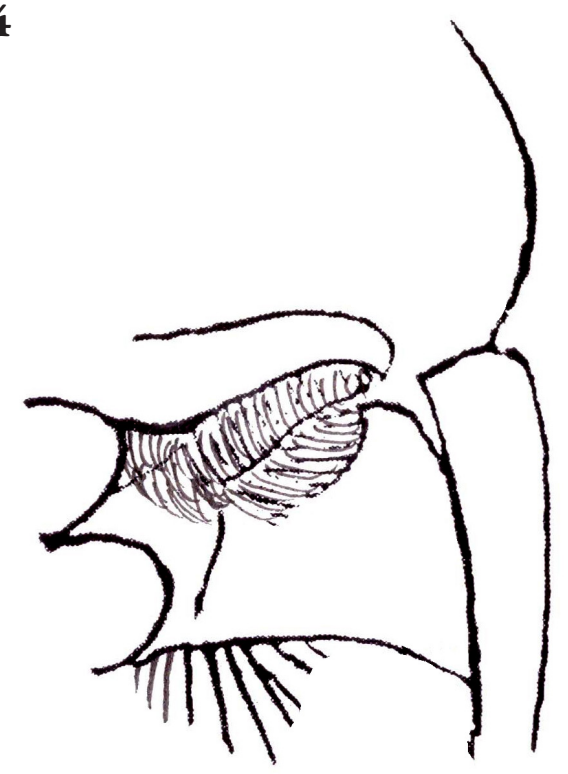

Figs 1-4. Setation of thoracal margin of Thorictus Germar, 1834 species, ventral view: $1=$ Thorictus walanganus John, 1964, 2 = Thorictus khinjanus John, 1964, $3=$ Thorictus kabulanus John, 1964, $4=$ Thorictus merkli sp. n. 


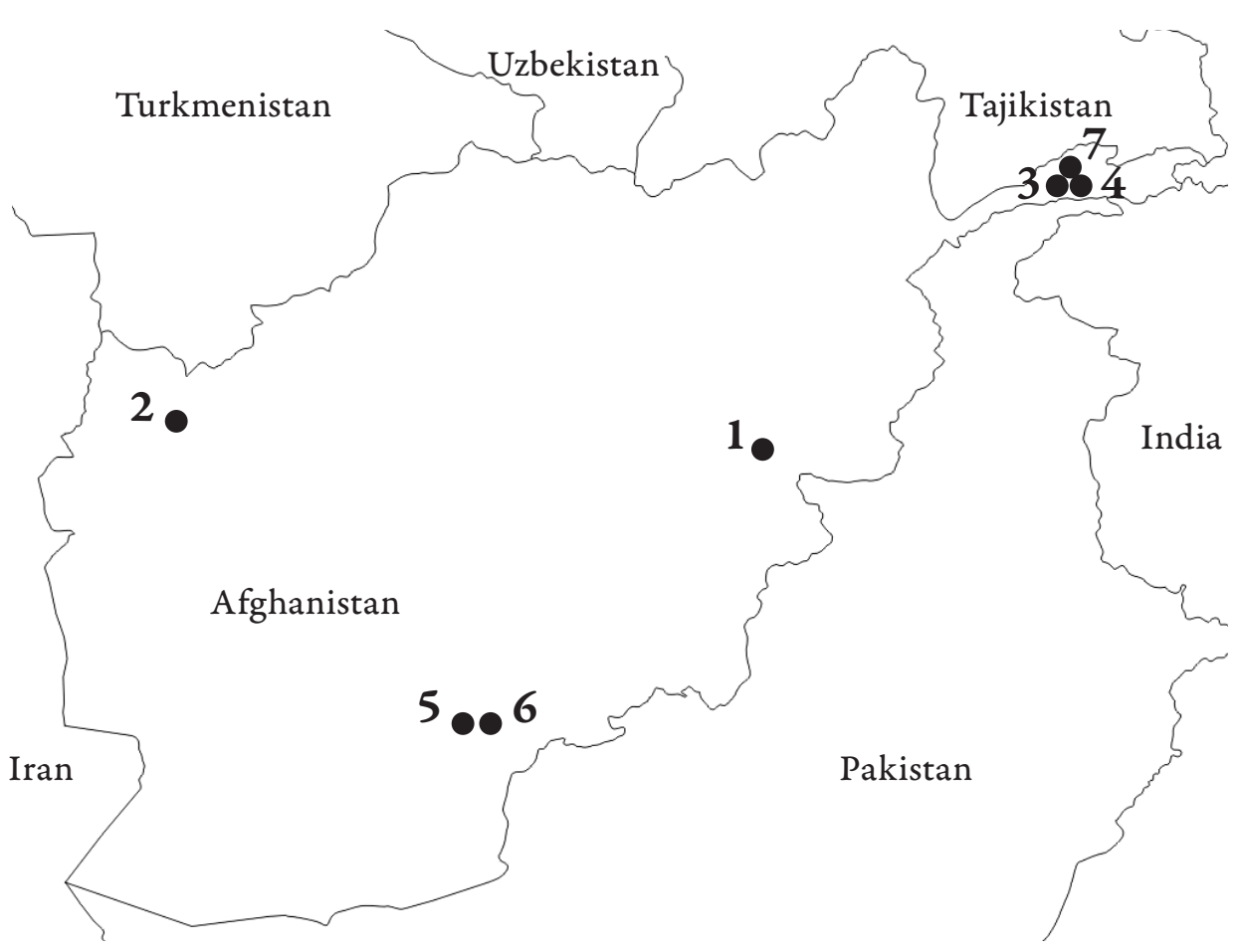

Fig. 5. Map of type localities of Thorictus Germar, 1834 species in Afghanistan: $1=T$. kabulanus John, 1964, 2 = T. merkli sp. n., $3=$ T. khinjanus John, 1964, $4=$ T. walanganus John, 1964, $5=T$. kandaharicus John, 1962, $6=$ T. angustus John, 1964, $7=$ T. quinquesulcatus John, 1964

Acknowledgements - I would like to thank my friend Ottó Merkl (HNHM) for the loan of the material studied here, and also anonymous reviewers for critical reading of my manuscript. The paper was supported by the Ministry of Agriculture of the Czech Republic, institutional support MZE-RO0118. 


\section{REFERENCES}

Háva J. 2015: World Catalogue of Insects. Volume 13. Dermestidae (Coleoptera). - Brill, LeidenBoston, xxvi + 419 pp.

HÁva J. 2020: Dermestidae World (Coleoptera). - Online: http://www.dermestidae.wz.cz [Accessed 30 August 2020.]

John H. 1962: Drei neue Spezies der Gattung Thorictus Germ. (Coleoptera, Thorictidae). Annales historico-naturales Musei nationalis hungarici 54: 283-285.

John H. 1963: Revision der Gattung Thorictus Germar (Thorictidae, Clavicornia Col.). Eine Bestandaufnahme, Kritik und Neubeschreibungen. - Entomologische Abhandlungen und Berichte aus dem Staatlichen Museum für Tierkunde in Dresden 28: 177-255.

John H. 1964: Acht neue Spezies von Thorictus Germ. (Thorictidae, Coleoptera). - Annales historico-naturales Musei nationalis hungarici 56: 331-339. 